\title{
ENCOUNTERS IN THE CONTEXT OF INSPIRING SUNDANESE MUSIC AND PROBLEMATIC THEORIES
}

\author{
Wim van Zanten
}

In the 1920s, the Dutch musicologist Jaap Kunst (1891-1960) and the Sundanese music teacher and scholar Machjar Kusumadinata (1902-1979) started their cooperation in developing music theory for West Java. In this essay, I will discuss elements of their theories and show how the present generation of music scholars in Bandung is dealing with the shortcomings of these theories.

As regards musical practice and practical knowledge, I will describe and reflect on my encounters since 1980 with the well-known Sundanese musician Uking Sukri (1925-1994), who taught Cianjuran music ${ }^{1}$ in the Netherlands for about half a year in 1988-1989. Uking Sukri has also performed on international stages, including the Netherlands. Finally, I will focus on the experiment by Uking Sukri's ensemble in combination with the jazz pianist Bubi Chen in 1989. The mere fact that this combination of instruments existed offers empirical evidence that the theory of tonal systems designed by Kusumadinata and Kunst does not hold for Cianjuran music. This experiment in West Java inspired my Dutch Cianjuran group, Dangiang Parahiangan, to start a similar experiment with the pianist Rob Agerbeek in 2009.

\section{Jaap Kunst}

Jaap Kunst is internationally recognized as one of the founders of the study of 'comparative musicology', for which he later introduced the term 'ethno-musicology' (Kunst 1950). His university training was in law, but he was an accomplished violinist. In 1919, he went to the Dutch East Indies

\footnotetext{
1 Also called Tembang Sunda or Tembang Sunda Cianjuran. It is solo singing and the accompaniment is provided by two zithers (kacapi indung and kacapi rincik) and a bamboo flute (suling), and sometimes also by a bowed violin (rebab). The instrumental form of Cianjuran, in which the bamboo flute takes the melodic part, is called kacapi-suling.
} 
for a concert tour with a pianist and a vocalist. ${ }^{2}$ Kunst was greatly inspired by the gamelan music of Yogyakarta and he decided to stay in the colony. He did administrative work for his living, gave violin lessons, but above all researched Indonesian music (largely in his spare time) until his repatriation in 1934.

From January 1930 until December 1931, Kunst held the position of 'government musicologist'. He competed for this post with the musicologist and researcher Johann Sebastian Brandts Buijs (1879-1939), who had also come to live in the Dutch Indies in 1919. ${ }^{3}$ Van Roon (1995) describes the fierce competition for this post between the two scholars who, until this point, had been on friendly terms. The discussions about the ideal candidate for this job also took place in the Netherlands. Important scholars, like the historian Johan Huizinga and the composer Willem Pijper, gave their opinions. Both Huizinga and Pijper emphasized the relation between art and science. Huizinga wrote 'Here is a field where art and science may be most intimately linked together, with art being capable of being preserved only by science'. Pijper wrote that a candidate for this post should 'combine the temperament of a creative artist, hence "musical intuition," with the intellect of a scholar'. He considered Kunst's recordings of music to be very important, especially for museums and phonogram collections, however, 'only a born artist $[. .$.$] with many years' European$ experience, $[\ldots]$ is likely to succeed in bringing Indonesian music to life for Western artists - and at the same time for the people of Europe. It is not just a codification of practices that is at issue: Indonesian musical research is much further-ranging than that' (Huizinga and Pijper, quoted in translation by Van Roon 1995: 70, 73; see also Van Zanten 2002: 938-943 and the chapter by Djajadiningrat and Brinkgreve in this volume). ${ }^{4}$

Due to budget cuts, the post of government musicologist was not continued and between 1932 and 1934 Kunst once again undertook administrative work in the Department of Education and Religion, which led him to move from Bandung to Jakarta (Batavia). Kunst left Indonesia in

2 See a photograph of this trio in Brinkgreve (2009: 143). Brinkgreve's book contains much personal information on Jaap Kunst and his 'co-worker' and wife Katy Kunst-van Wely (Brinkgreve 2009: 131-210).

3 See Heins (2008) for a curriculum vitae of Brandts Buijs.

4 These debates about the relation between art and science reflect ideas similar to those expressed in the nineteenth-century discussions concerning the Sundanese language (Van den Berge 1993, 1998; Moriyama 2005). For the Dutch in the second half of the nineteenth century, knowledge in prose was a better representation of reality than poetry, whereas for the Sundanese singer and his public poetry meant transmission of relevant knowledge (Van den Berge 1993: 205-209). 
1934 and in 1936 he became curator of music in the Tropical Institute in Amsterdam. From 1942 until his death in 1960 he also taught comparative musicology at the University of Amsterdam. Kunst published many books and articles on Indonesian music and he played an important role in international organizations (Kunst 1994; Heins 1994; Den Otter 1994).

The Society for Ethnomusicology in the United States honoured Kunst by establishing the Jaap Kunst prize 'to recognize the most significant article in ethnomusicology written by a member of the Society for Ethnomusicology and published within the previous year' (SEM 2011). In the Netherlands, the ethnomusicology section at the University of Amsterdam was called the Etnomusicologisch Centrum Jaap Kunst. ${ }^{5}$

When in Indonesia, Kunst lived most of the time in Bandung, West Java. Although his research took place in many parts of Indonesia, it concentrated on Central Java and, to a lesser extent, West Java. He collaborated with Sundanese researchers, notably with Machjar Kusumadinata from Sumedang. Under the influence of the 'blown fifth' theory, Kunst tried to develop a system that could explain the tones produced by the different gamelan in Java. ${ }^{6}$ In particular, he tried to make one theoretical system for the two tuning systems pelog and slendro (in West Java: pelog and salendro).

\section{Machjar Kusumadinata and His Collaboration with Jaap Kunst}

Machjar Angga Kusumadinata (also written: Mahyar and Koesoemadinata) was born in Sumedang, West Java, in 1902. His father came from upper class families in Sumedang and Tasikmalaya and his mother from

5 Also, in 1991 the Jaap Kunst Foundation was established in the Netherlands and Mantle Hood, a former PhD student of Jaap Kunst and well-known ethnomusicologist, became its honorary chair until his death in 2005. In 1995, the Foundation granted the first and last Jaap Kunst prize to Rüdiger Schumacher (1953-2007) for his work on Indonesian music. After the death of Egbert D. Kunst, son of Jaap Kunst, in 2009, the Jaap Kunst Foundation was dissolved on 19 June 2009. The author, who had been secretary of the foundation for some years in the 1990s, became the bewaarder van boeken en bescheiden (keeper of the books and documents) for seven years.

6 The blown fifth theory, developed by Erich von Hornbostel, is based on (1) a cycle of fifth intervals of 678 cent (a 'blown fifth' interval, supposedly produced by over-blowing a stopped flute, is 678 cent and a cent is one-hundredth of a Western semi-tone interval), instead of 702 cent for a Pythagorean fifth or 'pure fifth' for string instruments, and (2) the supposed 'tendency to equidistancy' that resulted in models to divide the octave in equal intervals. Already in the 1940s it was shown that the cycle of blown fifths was not very useful for understanding the different tone systems in the world. See further, for instance, Kunst (1948) and Van Zanten (1986: 100-102). 
a family of merchants. His father was head of mosque officials and able to perform Sundanese solo singing. This interest in music was passed on to Machjar, who learned to play the two-string bowed lute, bronze gamelan instruments, solo singing and to tune gamelan instruments (Herdini 2007: 2-17). Herdini remarks that Kusumadinata was very eager to learn playing the bowed lute from his uncle, but that he was not considered to be a good player (Herdini 2007: 15).

Kusumadinata was educated as a school teacher. After primary school he went to teacher training colleges until 1924. He then started to teach at a primary school in Sumedang. From 1933-1942, and again from 19471950, Kusumadinata became supervisor of music education in schools of West Java. In 1958-1959 he became the head of the Sundanese music section in the music conservatory (then KOKAR, Konservatori Karawitan) in Bandung. He remained involved in teaching music, also at the Bandung and Surakarta (Solo) conservatories, until his death in 1979 (Herdini 2007: 23-25, 122-127; Ensiklopedi Sunda 2000: 390).

According to Kusumadinata, he started to study music theory in 1916, when he was 14 years old, and he mentions his Dutch school teachers as being the first ones to explain Western music to him. Later on, he published several books and articles. In particular, he became known for his books with Sundanese songs for school children, in which the music was written down in cipher notation, which he had developed in 1923. From 1926-1968, Kusumadinata composed at least eight music dramas and in 1969 he was honoured by the Indonesian government with an Arts Award, Anugerah Seni (Kusumadinata 1969: 5-11; see also Herdini 2007: 127 and Ensiklopedi Sunda 2000: 390).

Kusumadinata mentions that his music books for primary schools were published and distributed by the Department of Education and Religion because of 'the recognition, confirmation and recommendation' by Kunst (Kusumadinata 1969: 6). He describes the start of his collaboration with Kunst in December 1927 as follows:

[...] I was introduced by him [Van der Dussen, inspector of education in Bandung] to Mr Jaap Kunst, a well-known musicologist. Mr J. van der Dussen had also in mind that I would be taught musicology that was based on pelog and salendro by Mr Jaap Kunst. [...] But [...] After talking to each other for some time about the tone systems pelog and salendro, Mr Jaap Kunst felt that it was not he who should teach me, but I who should teach him. Hence, since that first day we met, Mr Jaap Kunst came to visit me each Sunday at my house in Sumedang to hear from my mouth a "lecture" about "musicology based on pelog and salendro." That certainly sounds very odd: 
I gave "lectures" to Mr Jaap Kunst, a well-known musicologist. He also gave me lectures about Western music (Kusumadinata 1969: 5).7

In their correspondence between 1927 and 1954 Kunst regularly asked Kusumadinata for clarifications about Sundanese music terms. Kunst was asked to comment on Kusumadinata's theories and manuscripts for his books. Kusumadinata included some of his reports as supervisor of music education in schools of West Java in his letters and he regularly asked for Kunst's support for his work (Correspondence Kunst-Kusumadinata 1928-1954). ${ }^{8}$ In 1929, their collaboration resulted in an article about tone systems (Kunst and Kusumadinata 1929).

Kusumadinata initially followed Kunst's ideas and, like Kunst, he used the cycle of blown fifths for explaining the musical intervals in the different Sundanese tone systems. To put it simply, Kusumadinata's models were based on dividing the octave into equal intervals; he used models with 9, 10, 15, 17 and 23 equal intervals. In the 1950s, Kunst apparently became critical of the models developed by Kusumadinata, as these became ever more complicated (Van Zanten 1995: 230, n17). On 15 September 1953 Kusumadinata sent him the second print of his book 'A short outline of music theory' (Kusumadinata n.d.). In the accompanying letter he remarked that Kunst '[...] would find many new things, such as the salendro system with 17 steps, names of intervals, musical terms, etc.' On 21 October 1953, Kunst replied:

Your announcement that you have come to distinguish a total of 17 steps in slendro, startled me. At first, slendro seemed so harmless with its five steps; then it became 10; now it is 17 . Where does this lead us! (Correspondence Kunst-Kusumadinata 1928-1954).

In the same letter (21 October 1953), Kunst mentioned that Kusumadinata's eldest daughter Lina, who was going to study sociology in Amsterdam, had given him the books the previous evening. Lina had promised to help Kunst with translating this theoretical book (Kusumadinata n.d.) from Sundanese, but

\footnotetext{
7 All translations from Dutch, Indonesian and Sundanese are mine, except when stated otherwise.

8 It is interesting to note that before Kunst left Indonesia in 1934, Kunst and Kusumadinata addressed each other in their letters in a formal way: Waarde Heer Koesoemadinata (10 June 1933) and Zeer Geachte Heer Mr. J. Kunst (reply letter 13 June 1933). That changed after Kunst repatriated to the Netherlands: Beste Jaap! (3 August 1935, 9 September 1935) and Beste Machjar (reply 19 September 1935). In the later letters they also wrote more about personal matters.
} 
It would be advisable to have it appear also in a Dutch, even better an English translation. These days there is much interest for this music outside Java, particularly in the Netherlands, Germany and the Anglo-Saxon countries (especially in the USA). ${ }^{9}$

In his reply (19 December 1953) Kusumadinata remarked that this theoretical book in Sundanese was a short summary of his English treatise 'Musical art of Sunda'. He was still revising and complementing this English manuscript and had also started on a Dutch translation. Eventually, this book appeared in Indonesian in 1969. In the introduction, Kusumadinata writes that he felt that the international world should know about music theory based on the pelog and salendro tone systems. He had started this work already in 1940 with a manuscript 'Our musical art' in English, but it was still unfinished at the time of writing, 2 January 1969. Because he had been appointed at the conservatory in Solo, Central Java (starting 1 January 1965), he had decided to publish this revised manuscript, together with some of his other writings, in Indonesian (Kusumadinata 1969: 3). As far as I know, English or Dutch translations never appeared in print.

In 1953 Kusumadinata was presumably unaware of international discussions on music theory. At that time he was worried about other things: his poor health, his problematic position in the independent Indonesia as former collaborator in the Dutch educational system and the possibility that the Indonesian government might replace Sundanese by Western music. ${ }^{10}$ His last book on music theory (Kusumadinata 1969) does not have a list of references; in the text Kusumadinata only refers to Kunst and a few people in Java. In contrast, after leaving Indonesia, Kunst had become exposed to scientific discussions in the Western world and he was aware of the criticism on the blown fifth theory, also voiced by his friend Curt Sachs (Kunst 1948: 18-35, 1973: 45).

\section{Music Notation and Modal Theory as Developed by Kusumadinata}

The colonial setting was not favourable for studying Indonesian performing arts and literature. The Dutch colonizers were mainly interested in trade

9 In his letter of 17 February 1954, Kunst wrote again that it would be important to have Kusumadinata's book published in English. In the same letter he mentioned that his student Mantle Hood would defend his PhD thesis on a 'Javanese music-technical topic' in May of that year and he would ask him to send a copy to Kusumadinata.

10 See, for instance, his letters of 23 January 1951, 21 January $195^{2}$ and 29 April $195^{2}$ to Kunst. 
and economic revenue and for Indonesians, living in oral music cultures, the documentation of their musical knowledge had no priority. Around 1900 the situation became more favourable, mainly due to the 'ethical policy' of the colonizers and even more so after the Java Instituut, with a programme for enhancing culture in Java, was founded in 1919.

At that time, several Indonesian and Dutch scholars expressed fears that the existing forms of Indonesian music would soon be replaced by Western music. ${ }^{11}$ As a result, attention was given to the protection and preservation of Indonesian music by introducing formal teaching, research and encouraging musical practice; the development of music notation was thought to be necessary for this (Van Roon 1995: 65-66). At the 1921 conference of the Java Instituut, it was decided to organize a contest for developing a notation system for music in Java. Brandts Buijs became the chairperson of the committee organizing the contest and he published a report (Brandts Buijs 1924). As a result of this contest, the Javanese kepatihan cipher notation was developed. This notation system is absolute, like the Western staff notation: for instance, the note called nem in a particular gamelan is always notated with cipher 6 , although it is recognized that the pitch of nem is not exactly the same for all gamelan.

In contrast to the (Central) Javanese absolute system, Kusumadinata supplied two identical relative notational systems for Sundanese music of West Java: the da-mi-na-ti-la system and the cipher system $(1,2,3,4,5)$ in which $d a \equiv 1, m i \equiv 2, n a \equiv 3, t i \equiv 4$ and $l a \equiv 5$. The cipher system includes signs for sharpening $(-)$ and flattening $(+)$ tones, similar to the Western sharps and flats. These relative notation systems of Kusumadinata are still widely used in schools today. ${ }^{12}$ In Kusumadinata's relative system, which cipher is given to a particular tone depends on the function of the tone in the modal theory: in different modes ${ }^{13}$ the name $\underline{d a}(\equiv 1)$ is, for instance,

11 Kunst mentioned negative influences, like popular music and Christian songs (Kunst 1973: 4; 1947: 14-16).

12 See definitions of $d a, n a, t i$ and $l a$ in, for instance, Atik Soepandi (1995: 53, 136, 206, 116), Herdini (2007: 99-101). See also Kusumadinata's letter of 23 January 1951 to Kunst, in which he writes: 'To prevent Pelog and Slendro from destruction I intend to change my cipher system in the following way: instead of 12345 , I will write D (da) M (mi) N (na) $\mathrm{T}(\mathrm{ti}) \mathrm{L}$ (la) [...] What do you think about this?' (Correspondence Kunst-Kusumadinata 1928-1954).

13 When musicians consider two pieces of music to be different versions of 'the same musical structure', they distinguish two different modes of a piece of music. See Powers (1980) for an overview of the concept of mode in different music cultures and Van Zanten (1989: 131-134) for general remarks about modes in Sundanese music. 
given to a different tone. ${ }^{14}$ An example is provided in the Appendix. Further, Kusumadinata's relative cipher system runs from high or 'small' (alit, leutik, cipher 1), to low or 'great' (ageung, gedé, cipher 5) notes. This is in contrast to other cipher systems in the world, and in particular to the Javanese kepatihan system, which runs from low (cipher 1) to high (cipher 7$)^{15}$

Hence, we need to know Kusumadinata's modal theory before we are able to read or write music notated with his relative daminatila notation. That causes great problems in communication with people from other music cultures, who do not know Kusumadinata's theories. Moreover, Kusumadinata's modal theory needs thorough revision.

\section{Foreign Criticism of Kusumadinata's Theory and Notation}

Kunst has always tried hard to prove that 'non-Western' music was worthwhile and of equal value to Western music. The emphasis on developing music theories, based on much fieldwork, was part of his attempt to discover musical structure. Kunst and Kusumadinata, like most other music researchers of that time, concentrated on 'hard facts', like the description of musical instruments and pitch measurement of the produced tones. There was less attention for the process of making music in a social setting. The emphasis was on developing theoretical music models and the practical knowledge of musicians was only used in a limited way. Kusumadinata, in particular, produced several theories, thereby inventing many terms, ${ }^{16}$ but he often failed to check their relevance for musicians. We get the impression that Kunst and Kusumadinata tried to convince the general public that Sundanese music had to be taken seriously, also because it had an underlying theory.

Brandts Buijs was the first to point out that Kusumadinata's cipher notation did not reflect musical practice. He published a detailed survey of the proposed notational systems for Javanese music since the 1920s,

14 In Western music, an absolute system (C, D, E, F ...) is used next to a relative sol-fa system (do-re-mi-fa-sol-la-ti-do) in which 'do' may be any note, depending on the musical mode. In scholarly work the relative sol-fa system is rarely used. A Sundanese absolute cipher notation system also exists (Barmara and Achman 1958: 8-9), however, this is rarely used in schools.

15 Before the kepatihan cipher system was developed, some Javanese notation systems also ran from high to low notes; see Brandts Buijs (1924: 11) and Kunst (1973: 349-350, 442-443).

16 For instance, in a letter of 17 March 1929 to Kunst he writes that he 'discovered new tones of the pelog system' (Correspondence Kunst-Kusumadinata 1928-1954). 
including the cipher-notation system developed by Kusumadinata for Sundanese music (Brandts Buijs 1940). At that time, the kepatihan cipher notation for Javanese music had become firmly established, as it still is today. Brandts Buijs accepted the Javanese cipher notation as being practical and useful, but he was very critical of the cipher notation developed by Kusumadinata for Sundanese music. One of his major objections was that Kusumadinata did not take into account that Sundanese (and Javanese) musicians always give the same name to a string or slat, regardless of which musical mode they are playing in. For instance, the third string on a zither is always called panelu, although it is tuned differently in sorog and pelog (Van Zanten 1995: 214-217).

In the period between 1940 and 1965, there were few musical encounters between the Indonesians and the Dutch, due to the political circumstances: Second World War, independence war (1945-1949) and the tensions in the post-colonial period under Sukarno. It took until the 1970 s for Brandts Buijs's criticism to be followed up by other foreigners, who also doubted the usefulness of Kusumadinata's modal theory (Kartomi 1973: 88; Heins 1977: 85, n2;17 Tamura 1977: 64; Rahn 1979: 77). However, they did not provide any alternative theories. Hence, when preparing my PhD fieldwork on Cianjuran music in 1980, I was confronted with the problematic modal theories of Kunst and Kusumadinata, which seemed rather distant from musical practice. I decided that learning to play the music myself, measuring zither tunings, observing the tuning process of these zithers and interviewing the players ${ }^{18}$ might throw some light on the tuning models and modes in Sundanese music.

In the 1980 , there was a general aversion to measurements and a 'positivistic approach' in ethnomusicology. In the United States, in particular, ethnomusicology research had almost become anthropology and omitted music-technical discussions. As far as I was concerned, I had no objections to measuring pitch and computer analysis, if done in a proper way. One of the reasons is that I had a background in theoretical physics and mathematics. I did not want to limit myself to symbolic meanings as represented by music, but also wanted to report 'tangible results, or "facts" , to zither players and Sundanese fellow researchers (Van Zanten 1989: 5).

17 After 1940, Ernst Heins was the first Dutch music researcher who did fieldwork on Sundanese music in 1967-68 (Heins 1977: i).

18 I did most interviews in Indonesian, which I speak fairly fluently, after using it for teaching at the Universitas Indonesia in 1976-79. In some cases, I used my more limited knowledge of Sundanese. 
However, in line with the general trend in ethnomusicology, I wanted to participate and learn to perform, in order to enhance the understanding of music concepts (Van Zanten 2002: 948-952). For me, scholarly work had priority and my skills in performing Cianjuran music have always been fairly limited. ${ }^{19}$

My emphasis was on learning from the practical knowledge of musicians, rather than on music theory from the conservatory staff. I therefore asked the well-known zither player Uking Sukri whether I could stay in his family's home in Ujungberung when doing my fieldwork and he agreed. I have learned much from his vast musical knowledge, his music lessons and also from the many conversations I had with him, his wife, the singer Nenden Asyani, and many other family members and visitors. ${ }^{20}$

On the basis of tone measurements of 56 zithers and observation of the tuning processes, I showed that none of Kusumadinata's (and Kunst's) theoretical models for tone systems hold for the tunings of zithers in Cianjuran music (Van Zanten 1986: 100-105). Simply said, playing the five basic intervals of the pentatonic systems on a piano would be a better approximation to the pelog and sorog tunings of the zithers than any of their theoretical models. I also showed that the salendro tuning of the zithers was conceptually considered to be equidistant, although the measurements showed a slight, but significant, deviation from equidistancy.

During my fieldwork, I also learned that, in practice, if zither players use a notation system, it will mostly be an absolute cipher system as used by Barmara and Ida Achman (1958: 8-9; see also the Appendix of this essay), and not Kusumadinata's relative system (Van Zanten 1986: 107, fn 5; 1989: 120-122). I showed that Kusumadinata's relative cipher notation led to much confusion about, for instance, the notation of the family of sorog tone systems (Van Zanten 1995: 218). Kusumadinata's cipher notation was only used in schools. The musician Uking Sukri always used to write music with the absolute cipher system, although he had learned Kusuma-

19 See also Witzleben (2010) for a recent overview of how engagement with performance has shaped, and continues to shape, the ideas and theoretical perspectives of ethnomusicology and ethnomusicologists. Kunst never used musical participation as a means for understanding Indonesian music.

20 The main musical structure of Cianjuran is supplied by the large zither (kacapi indung) player. My teachers included the kacapi indung players Uking Sukri, Bakang Abubakar, Rukruk Rukmana, Tjatjih Djakarsih, and further the instrumentalists Dacep Eddi (rebab) and Burhan Sukarma (suling). Earlier, from 1976-79, when teaching at the University of Indonesia, Jakarta, I learned to play the kacapi zither from Sulaeman Danuwijaya, who used older playing techniques. 
dinata's relative daminatila system in school. However, after he became an honorary staff member at the conservatory, he published a book with songs in which he used the relative notation system of Kusumadinata (Uking Sukri 1989). When I questioned him about this, he answered that he had been asked by the publisher to adopt the Kusumadinata system.

In fact, the problem is not so much the existence of a relative cipher notation system, but the fact that music schools do not use an absolute notation system: the Western staff notation and the absolute cipher notation system by Barmara and Ida Achman are hardly used in publications. Jaap Kunst contributed to this. In his letter of 9 September 1936, Kusumadinata asked Kunst's advice on notating Javanese and Sundanese songs for people outside Java. 'For this it is urgent that they are notated in the international notation' [that is the Western staff notation], so how could he best represent the Javanese note nem, as $\mathrm{B} b$, A or C? Kunst replied in his letter of 19 September 1936 to Kusumadinata: he found it difficult to advise him, but thought that it would be better to stick to Kusumadinata's [relative] cipher notation and not to use the [absolute] Western notation. In his letter of 13 February 1937 Kunst repeated: 'I think it is better if you stick to your cipher system' (Correspondence Kunst-Kusumadinata 1928-1954).

One may wonder why Kusumadinata's theories and notational system are still in use today, although their shortcomings are recognized by Sundanese theorists and musicians. One explanation may be that Kusumadinata was systematic and diligent, and that the well-known Kunst leaned heavily on Kusumadinata's theories. Further, Kusumadinata wrote many books for primary and secondary schools in which his daminatila notation was used. These books have been widely used, partially on Kunst's recommendation. In a letter dated 2 February 1937, when Kunst was back in the Netherlands, Kusumadinata wrote: "The dissemination of my cipher notation goes very fast. I have won almost the whole of West Java for my ideas. In my spare time I give presentations about music everywhere'. Earlier, on 3 August 1935, he wrote to Kunst that he was preparing a book with Javanese songs and hoped that his (daminatila) notation system would also be adopted in Central and East Java (Correspondence Kunst-Kusumadinata 1928-1954).

Another reason for the persistence of Kusumadinata's ideas might be that the Sundanese wanted to have their own cipher notation for music, one that was different from that commonly used by their Javanese neighbours (the kepatihan notation system), thus underlining that the Sundanese 
were different from the Javanese. Weintraub (1993: 37) summarizes the reasons for the persistence of Kusumadinata's theories as follows:

The problem is not so much that Kusumadinata's theories were wrong or even a "mistranslation" of actual practice, but that there has been a lack of continuing debate and criticism within the conservatory. It is difficult for insiders to challenge a legendary figure such as Kusumadinata.

In the Sundanese (and generally, the Indonesian) educational system, an openly-critical approach to ideas of teachers is rarely encouraged. However, in 2001 Sundanese scholars began to criticise Kusumadinata's theories openly. One of them, Heri Herdini, underlined the difficulty of criticizing a musical forefather like Kusumadinata when he pointed to the 'hidden meaning' in Kusumadinata's daminatila notation system: '[...] the term "Daminatila" that was created by Radén Machjar Angga Koesoemadinata was truly based on concepts and extraordinary understanding of the essence of human life'. Implicitly, 'it contains the life philosophy for each human being by continuously reminding him/her of his/her creator' (Herdini 2007: 72-76).

\section{Critical Articles on Kusumadinata's Theories by Bandung Scholars in 2001-2004}

Musicians can ignore theories and just play the music they learned to play without knowing these theories. The theories of Kusumadinata about tone systems and modes did not become part of musical practice and only exist in music schools (see also Herdini 2007: 82). Staff members in these schools, most of whom also perform, seem to live in two worlds: their musical practice outside the teaching context is different from the theory they teach in the schools (Van Zanten 1995: 229-230). In 2001-2004 this issue was addressed in four articles that were critical of Kusumadinata's theory, and which appeared in the Panggung journal of the Bandung conservatory (STSI): Hermawan (2001), Hernawan (2002), Herdini (2004) and Priadi Dwi Hardjito (2004). Here, I will focus on Hermawan (2001) and Herdini (2004).

Heri Herdini (2004: 62-63) wrote that until that time the theory of Kusumadinata was considered a 'monumental work', and that Kusumadinata's books were still compulsory for the courses on Sundanese music. The experts and scholars of music seemed to feel that it was taboo to revise the music theory of Kusumadinata. However, there had been much criticism by foreigners (Tamura, Heins, Van Zanten) and therefore it seemed 
necessary to him to prove whether there were shortcomings in Kusumadinata's theory or not. The foreigners 'limited their critical remarks only to comments that were not followed by results that proved their statements' (Herdini 2004: 54-55).

In the first of these four articles, Deni Hermawan (2001) investigated the extent to which the theory of Kusumadinata corresponds to existing practice. He measured three tunings of each of four players of the kacapi zither and listed the tone intervals in his publication. He concluded (Hermawan 2001: 83) that

the theoretical tone scales of Raden Machjar [...] were not in correspondence with the practical tone scales that originated from the "feeling for musical modes" [rasa laras] of the artists.

Dedy Hernawan (2002: 55) also remarked that the tone systems are a question of 'feeling' (rasa) of an individual player and that the theory of Kusumadinata did not lead to a standardization of tunings in practice. In the title of his article he stated clearly that 'there is no relation between the practice of tone systems and the theory of Machjar'.

Herdini confirmed the findings of Hermawan, but his results were based on more measurements. He presented mean intervals calculated from 52 instruments: 30 gamelan instruments, and 22 string instruments (Herdini 2004: 64-65). ${ }^{21}$ These results of Hermawan (2001: 74-79) and Herdini (2004: 65) confirmed my conclusions about the pelog (degung) and sorog (madenda) tone systems in Cianjuran music: the Western equal-tempered model is better than any of the models suggested by Kusumadinata and Kunst (Van Zanten 1986: 102-103, 1989: 125).

Herdini's results for the salendro tone system differ in detail from what I had found earlier (Van Zanten 1986: 94, 1989: 125). This may have been caused by the fact that his measurements were taken from gamelan instruments, together with zithers and bowed violins, whereas my measurements concerned a homogeneous sample of kacapi indung zithers. Unfortunately, Herdini did not comment on these small but important differences. He did not supply the $5^{2}$ individual measurements, or the results for the separate groups of gamelan and string instruments. Doing so, might have given us some clues about the difference between his and my mean salendro tunings.

21 The string instruments were: 10 'tarawangsa instruments (rebab and kacapi),' 7 kacapi indung and 5 rebab. No more information was given on the 30 measured 'gamelan instruments'. 


\section{Towards A New Modal Theory}

The 2001-2004 publications are a necessary step towards developing a new modal theory for West Java. However, methodological issues should be carefully discussed and pitch measurements should be reliable. ${ }^{22} \mathrm{We}$ must take into account that the conditions under which the research at STSI is carried out are poor. Staff members do not have the same resources for their research as those in Western institutes. Although most of my publications have been presented to the libraries and to some individuals, relevant literature is often not available. Further, the level of English among most staff members is poor, especially among those older than 40 years. On the whole, the Indonesian tertiary level of education is below the level of neighbouring countries like Malaysia and the Philippines.

It is also a question of a changing balance between theory and musical practice. These days, staff members, mainly trained for and interested in music making and teaching, are put under pressure to publish articles and books. For the STSI and its staff it has become a question of 'publish or perish'. Very skilled performing artists are invited to become scholars, while their knowledge of the methodological issues involved in research needs improvement. It seems that there still is a large gap between their oral music culture and the international scholarly culture of written publications.

In their articles of 2001-2004 staff members of STSI Bandung have confirmed the flaws in Kusumadinata's theories, thereby concurring with my conclusions for Cianjuran (and kacapi-suling) music: in the pelog and sorog tone systems the musical intervals are almost the same as those found in the equal-tempered Western tuning. We also agree that the measured salendro intervals are not exactly equidistant. However, the Bandung scholars did not address my statement that in Cianjuran musical practice salendro is treated as an equidistant pentatonic system. In the future, the discussion on the Sundanese musical modes will have to take this into account: the measured unequal intervals of the salendro tone system coexist with the 'musical fact' that, in practice, salendro is treated as an equidistant system. In a cognitive sense, the Sundanese salendro tone system is equidistant (Van Zanten 1986: 95-96, 1989: 126; Cook 1993: 59, n10).

22 The results presented by Hermawan (2001: 74-79) for the separate tunings show that there is strong evidence that the measurements by Hermawan and Herdini were not statistically independent. 
Hence, Sundanese musicians, singing a song with the accompaniment of a zither with a salendro tuning ('almost equidistant'), have no difficulties in moving the song one salendro step down or up. It remains 'the same' song, although the transposed melody consists of a sequence of intervals that is slightly different from the original sequence. This needs to be used in developing a new modal theory because it is an indication that the Sundanese modes are based on the structural, rather than on the melodic function, of the tones. ${ }^{23}$

The first steps, taken by myself (Van Zanten 1989: 156-159) and Simon Cook (Cook 1993) in the analysis of transformations of songs in the different tone systems need to be followed up. After discarding Kusumadinata's theories, at least to a large extent, scholars should develop a new modal theory, preferably based on experimental research. This will also mean that the daminatila notation system should be replaced in scholarly work by an absolute notation system, certainly if international communication is sought.

In the remainder of this essay I will discuss how my encounters with Uking Sukri inspired the playing of Cianjuran music in the Netherlands. In particular, I will discuss the combination of the ensemble consisting of zithers and bamboo flute with a Western piano, because this clearly shows that the theoretical models of Kusumandinata deviate from empirical evidence.

\section{Collaboration with Uking Sukri}

On a modest scale, I have tried to involve practitioners in my scholarly work by inviting Uking Sukri and Yus Wiradiredja from the Bandung conservatory to teach in the Netherlands. Pa Uking ${ }^{24}$ (see image 9.1) had been my teacher and main informant for my $\mathrm{PhD}$ research since 1981. In 1987-1988, he came to the Netherlands for about half a year, and together we developed a method for playing Cianjuran, including audio materials and transcribed music (see Van Zanten 1995: 220-227; Van Zanten and

\footnotetext{
23 Powers (1980: 123) formulated this structural-melodic continuum as 'the modal spectrum between abstract scale and fixed tune'; Indian modes (raga) are 'nearer to the tune end' and the modes of Javanese gamelan (pathet) are 'nearer the scale end'.

24 'Mr/ Father' Uking; in West Java often Mang Uking; that is, 'Uncle' Uking.
} 


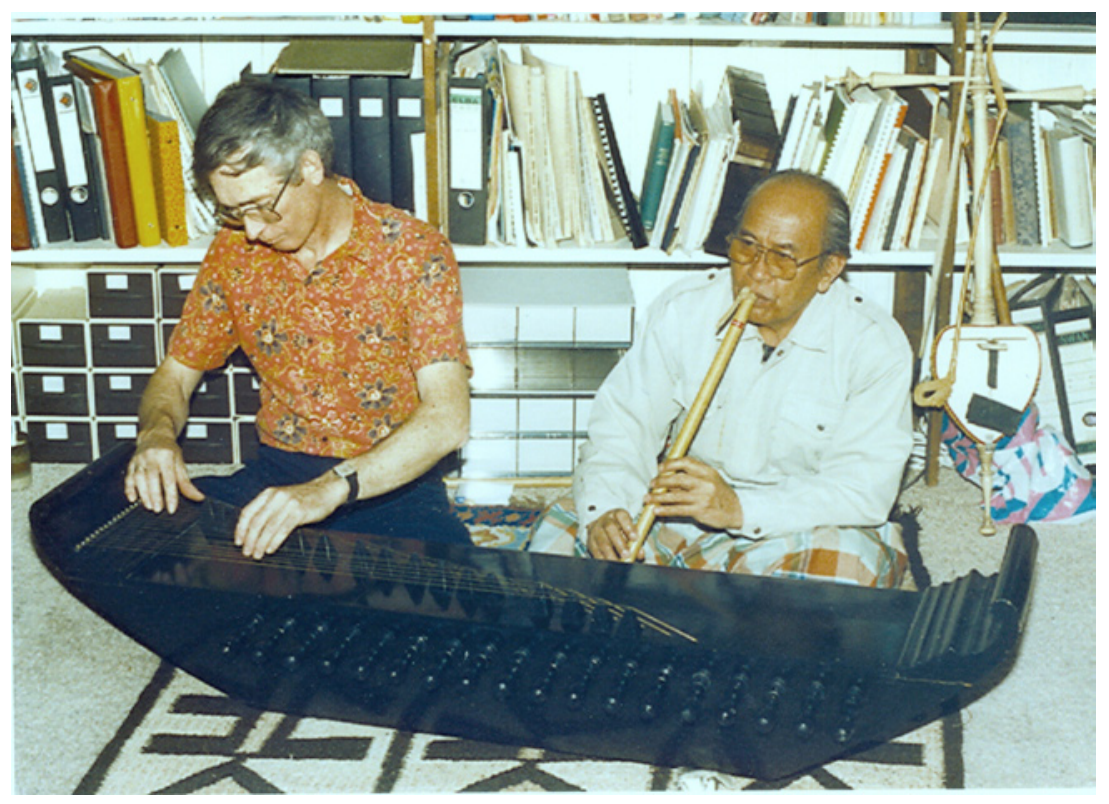

Image 9.1 Uking Sukri on the suling bamboo flute and the author on kacapi indung zither. Aarlanderveen, the Netherlands, 1988.

Uking Sukri 2004). ${ }^{25}$ Pa Uking taught students in Leiden and Amsterdam ${ }^{26}$ and since that time I have organized a Cianjuran music group: Dangiang Parahiangan ('the spirit of West Java'). Learning to play Cianjuran music also became an optional part of my Anthropology of Music course at Leiden University and it was based on the course materials developed in 1987-1988 (Van Zanten and Sukri 2004). In 1992, Uking Sukri came to the Netherlands again, for about one month, before he travelled to England for a series of concerts and workshops. Yus Wiradiredja, whom I first met during my fieldwork in Bandung in 1981, came to the Netherlands for two

25 This research on the practical aspects of Cianjuran music was supported by the Programma Indonesische Studies (PRIS) project KA 109. In their letter of 27 November 1986, the chair A. Teeuw and secretary Ch.F. van Fraassen wrote to me that the Dutch steering group was 'in favour of a close and mutual Dutch-Indonesian research cooperation' as formulated in my proposal. I am very grateful for the understanding and support for this music-practical project.

26 There were $30-35$ participants who regularly attended these classes by Uking Sukri. Several of them (Jos Jansen, Jean Hellwig, Renadi Santoso and Sinta Wullur) continued in a variety of ways with musical encounters in West Java. 
months in 1999, mainly to help me analyse the ornaments of Cianjuran singing in more detail.

For me this cooperation was of great academic interest, but it also supported the performing of Cianjuran music in the Netherlands. We can assume that for Pa Uking and Yus Wiradiredja the experience of living in the Netherlands for some time, ${ }^{27}$ together with the increased prestige in West Java and the financial reward, was important. For instance, after his stay in the Netherlands in 1987-1988, Pa Uking used part of the money he had earned to improve his house. Yus Wiradiredja used the money he earned in 1999 to produce cassette tapes with his newly composed 'ethnic music with an Islamic flavour'; see more on Yus Wiradiredja and this music in Van Zanten (2011).

Uking Sukri considered it important to support my documentary work: he wanted me to get every detail correct. He already expressed his willingness to come to the Netherlands in 1982 for further cooperation on the documentation of Cianjuran music (see image 9.2). Pa Uking often said that, in the future, people would need to visit Leiden if they wanted to find out about Cianjuran music. My reply would then be that this might become true only for the theoretical part, as in the Netherlands the students lacked the Sundanese soundscape: the people with first-hand experience of Cianjuran music lived in West Java. See a report in the weekly magazine Manglé (Hana Rs 1992: 46) for more about Pa Uking's comments on my research and his stay in the Netherlands in June-July 1992.

Uking Sukri28 was born in the centre of Bandung into a middle-class family in 1925. He finished primary school and three years of technical vocational training. As the child of an Islamic family, he also attended an Islamic school for one year. When he left school, because his parents could not afford the school fees, Uking Sukri started to work. From 19401942 he worked daily from 7 to 2 o'clock as a technician at the public works department of Bandung and from 5 to 8 o'clock in the evening in a shop, Toko Tokyo that had a Japanese owner. During this time he learned some Japanese. At an early age Pa Uking learned to play the kacapi zither and to sing Cianjuran songs in an informal way; at 15 he was accepted as

27 For instance, I attended a concert by the Residentie Orkest in The Hague with Uking Sukri; Bernard Haitink conducted, among other works, a Bruckner symphony. Pa Uking was always very interested in such new experiences.

28 This section is largely based on the many discussions I had with Uking Sukri and also on the autobiographical notes that he wrote, on my request, when staying in our home in Aarlanderveen, the Netherlands (Sukri 1988). 
player of the small zither by the music group Rengganis, which included the famous zither player O. Tarya.

From 1945-1947, during the struggle for political independence, he joined the Indonesian army in Bandung. After this period, he again worked as a technician, from 1948-1950 in a textile factory in Garut, and from 1950-1953 in a Bandung factory that made all kinds of products for the Post, Telephone and Telegraph office. During this last post in Bandung, Pa Uking also worked as an honorary musician at Radio Bandung. From 1953 onwards he was full-time employed as a musician at Radio Bandung, and he stayed there for 30 years, until his retirement in 1983 . Initially, he played the small zither (kacapi rincik). In 1966, the player of the large zither, O. Tarya, died and Uking Sukri became the kacapi indung player in his place. From 1970-1984 he was leader of the radio group for Cianjuran music. After his retirement from the radio, Pa Uking became honorary teacher of the Cianjuran zithers at the Bandung music and dance conservatory (ASTI, now STSI) until his death in 1994.

Pa Uking was an all-round musician. When he became well-known he also taught Cianjuran singing and playing to amateur groups in Bandung and at tea estates near Bandung. During this period he made several overseas trips to perform in Europe. He started to learn some English, and managed to find his way in France, the Netherlands, England, and a few other countries. Pa Uking was also recognized as one of the best zither builders. He built about 10 sets of zithers (kacapi indung plus kacapi rincik) for me. See further information on Uking Sukri in Enip Sukanda (1996) and Van Zanten (1989: 53, 60-61; 2005).

\section{Kacapi-suling Ensemble with Piano in 1989-199o}

Musical experiments with Western instruments in Sundanese, and more generally Indonesian, music have been documented since the beginning of the twentieth century. One such experiment took place in 1989-1990 when Uking Sukri collaborated with the jazz pianist Bubi Chen in playing kacapi-suling music with piano. In 1989 the cassette tape Kedamaian (1989) was produced by Hidayat, and in September 1990 there were concerts in Jakarta (image 9.3). The owner of the Hidayat Company, Bill Firmansjah, was a jazz fan and instrumental in combining the kacapisuling ensemble with a jazz pianist. Hidayat had already produced several cassette tapes with jazz, as well as several with Cianjuran and kacapisuling music, especially by groups led by Pa Uking. The combination of 
Denganhoremat,

$$
\begin{aligned}
& \text { Saris, } 29 \text { Jumigso } 2 . \\
& \text { tepada. } \\
& \text { yth: Sar. WimvanZomten } \\
& \text { di Vegri belanda }
\end{aligned}
$$

Wim! Bagarmana hhabare angan keluarga sehat? onja dan bahajia? ham dengan qRou sehat remma walaupen bekeria begitu agah appe, dengan finduh: tempat conecet yang begitujauk. Ltam meresox monyosal kavens tidik dapat pergike Nyes Belanta sesuni dengan perminitain Wim, wrataupun teams bessecin untuk pergs lee Noderlan, pithate Andonesix sebetulnyi tidak kebexaton hanya hareus melakis freosour pernerintaken, tetap Kalau Wm dapat menempuhny iter belih baite. Sihrk Peraness sama sekch indak beskebratan kasma coneert telah sebsas. Halau keh in tizak bahavil, tetap pa Ukmy becsedir pergita Negres Belank sesuridengan rencank wim. paik lam wakin setelihtambah tee Intonerix. Sckin decula Terma kasil.

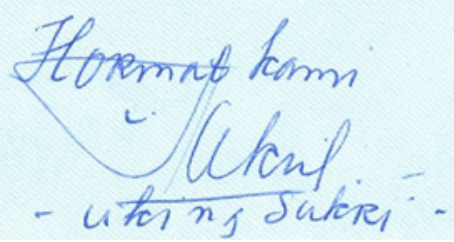

Image 9.2 Letter of 29 June 1982 to author by Uking Sukri when he was on a concert tour in France. Uking Sukri writes that the ensemble is healthy but a little tired, because they often had to travel long distances for their concerts. At this time, 1982, he already expressed his willingness to come to the Netherlands: if it cannot be arranged this time, he would like to come another time. 
kacapi-suling with piano was, however, not a great success, ${ }^{29}$ although in 2005 Bill Firmansjah told me that the cassettes had sold 'normally'.

The title of the tape, Kedamaian, is derived from damai, peace, agreement. According to Pak Uking, this name refers not only to the peaceful combination of the different kinds of music, but also to the possibility of peaceful co-existence of different philosophies of life. The text introducing the cassette tape was written by the well-known Bandung jazz musician Harry Roesli (1951-2004) who had previously studied at the Rotterdam conservatory. He wrote (in my translation from Indonesian):

$[\ldots]$ if Bubi Chen, a master jazz pianist that we have these days, plays together with the kacapi-suling group of Mang Uking, it is not just a question of the combination of Western and Eastern, or traditional and modern music. It is more than that, it is an exploration of the aesthetical expansion and may be seen as the birth of a post-modern music. Imagine, the aesthetical world of kacapi-suling is beautifully infiltrated by Bubi Chen with forms of jazz improvisation and substitution. Imagine a sacral, almost minimalistic harmony and, evoked by the jazz idioms from Bubi Chen's playing with wide [luas] chords, and even more by the modern technique of superimposing. [...] It is no exaggeration when I pay my respect to Bubi Chen and Pak Uking, and at the same time express my happiness about the birth of their spiritual child (their work) that I consider to be a "master piece" (Kedamaian 1989).

I would describe the playing style of Bubi Chen as an adoption of the syncopations of the large zither in combination with improvisations on the patterns of the small zither with occasional trills. As has been explained above, the Western equal-tempered tuning of the piano can reasonably well reproduce the pelog and sorog tunings of the kacapi zithers. The piano tuning is close to the tuning of the zithers and the bamboo flute, although there remains some tension between the tunings and timbres of piano and the kacapi-suling ensemble. However, this was musically completely acceptable to these accomplished musicians. ${ }^{30}$

29 There were 'no more than 40' attendants on the first concert evening in Jakarta, 21 September 1990 (Ati 1990: 12).

30 This combination of the kacapi-suling ensemble with a piano is a clear indication from musical practice that the tuning models of Kunst and Kusumadinata are less suitable for describing the pelog and sorog tunings of the kacapi-suling ensemble than the Western equal-tempered model used to describe the piano tuning (pelog: F, E, C, Bb, A, F and sorog: F, E, D, Bb, A, F; see above and a thorough analysis in Van Zanten 1986: 102-5; 1989: 124-7). Later, in 2002-2003, the same was demonstrated by Yus Wiradiredja, who used the madenda or sorog tone system in all songs on his cassette tapes with 'ethnic music, inspired by Islam' and he combined instruments like the suling and kacapi with a keyboard tuned in the equal-tempered Western tuning (Van Zanten 2011: 262, n18). Moreover, in pop music since 


\section{Dangiang Parahiangan in the Netherlands}

Inspired by the recordings on the cassette tape, Kedamaian, the music group Dangiang Parahiangan from the Netherlands, also started experimenting in 2009. Our pianist was Rob Agerbeek, who is a jazz, boogiewoogie and blues performer (image 9.4). Rob Agerbeek was born in Indonesia but, unlike Bubi Chen, he did not know kacapi-suling music. Maybe, therefore, he took more freedom and his playing deviated more from the kacapi-suling idiom than Bubi Chen's. My impression was that his sound colours were more vivid. The zithers in the kacapi-suling group mostly played the usual, very strict, patterns of 2 or 4 gong cycles of 8 (or 4 or 16) beats. In contrast to the Kedamaian (1989) music, we rarely used the suling together with the piano. Instead, we experimented with percussion instruments. We first tried a Sundanese kendang, but later we found that the sound quality of the Indian tabla drums combined better with the other instruments.

At the concert on 22 May 2010 at the Tong Tong Festival in The Hague, the music with piano was alternated with 'common' Cianjuran singing and instrumental kacapi-suling episodes. ${ }^{31}$ For instance, the last item in the pelog tuning was basically the piece Catrik with a solo introduction by the large zither and the bamboo flute. Catrik was then played by just the kacapi-suling ensemble, after which the flute stopped playing and the improvising piano came in, later joined by the tabla drums. After four to five minutes, the tempo was increased and it stayed this way until the end (about one to two minutes). The next item, which was the first piece in the sorog tuning, consisted of the 'usual' Cianjuran songs with a female vocalist: Kapati-pati and Eros, and was followed by one verse of the metric song Gandrung Gunung. After the singing, the improvising piano joined Gandrung Gunung, followed by the tabla. Consequently, our performance covered a wider range of possibilities than the tape Kedamaian (1989).

This performance seems to have been a success. I estimate the number of attendants to have been between 100 and 150. The Dangiang Parahiangan players and Rob Agerbeek are grateful to the Uking Sukri ensemble and Bubi Chen for their inspiring recordings.

1960 Sundanese zithers and flutes have regularly been combined with keyboards and other instruments tuned according to the equal-tempered Western tuning.

31 The musicians were Rob Agerbeek, piano; Ronald Bergman, suling, kendang, tabla; Igor Boog, kacapi indung; Tuti Hasanah, vocalist and kacapi rincik; Wim van Zanten, kacapi rincik. 
The Jakarta International Festival of
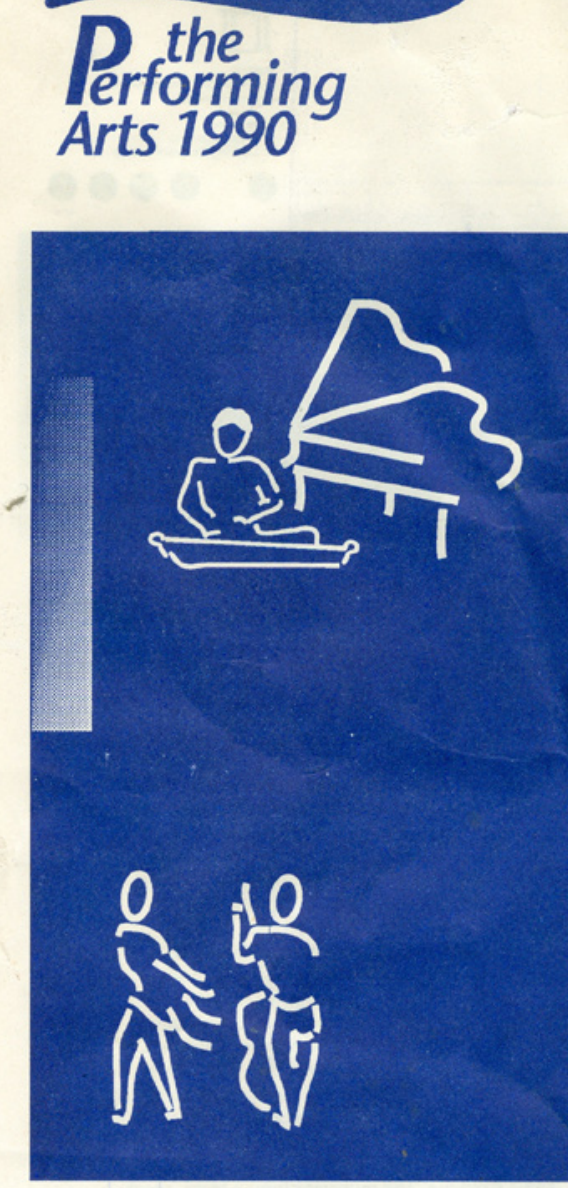

\section{Bubi Chen \& Mang Uking Trio Jazz with Kecapi Suling Indonesia}

\section{1, 22, 23 September 1990, 8.00 pm Gedung Kesenian Jakarta}

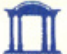

Patron
H.E. Wyogo Atmodarminto

Commitee

of Cecung Kesenian jakart
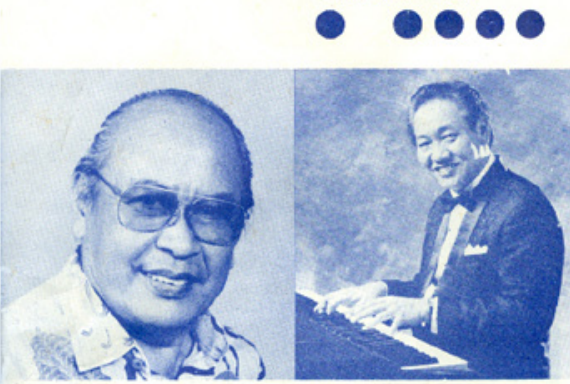

Sudah berpuluh-puluh pemusik mencoba bermain diwilayah tradisi digabung modern, bahkan

beberapa komposer dunia pernah bermain musik

tradisi kita dalam idiom orkes barat. jika Bubi Chen bermain bersama Mang Uking Trio ( pemusik

tradisi, pemain kecapi ) bukannya latah atau

eksperimen, apa lagi coba-coba ... bukan! Sejarah mencatat dalam kaset "Kedamaian " yang

diproduksi dan diedarkan oleh Hidayat Audio

Bandung. Mereka bermain bersama, berbicara dalam bahasa yang sama, berjalan seiring tidak saling menuntun, menciptakan sesuatu yang enak untuk dinikmati ....... itulah seni.

$\boldsymbol{N}_{\text {umerous musicians have tried thier best to }}$ present a combination of traditional and modern music. Some of the Internationally renowned among them have at one time even played our traditional music in the western orchestral idiom. Now, Bubi Chen appearing together with Mang Uking Trio ( Traditionál kecapi players ), does not mean that he is experimenting or just trying ... far from it ! History has proven such in the album " Kedamaian " produced and distributed by Hidayat Audio Bandung. The musicians form a team, speak the same language, walk side by side without hesitation and create something pleasent to be enjoyed ... that is art !.

Tickets Availlable : Cedung Kesenian Jakarta Jalan Cedung Kesenian 1 Jakarta 10710 Advance Bookings and Information Phone (021) 3808283 Fax (021) 3810924

Image 9.3 Announcement of the 'Jazz with Kecapi Suling' concerts by Bubi Chen and the 'Mang Uking Trio' at the Jakarta International Festival of the Performing Arts, 21-23

September 1990. 


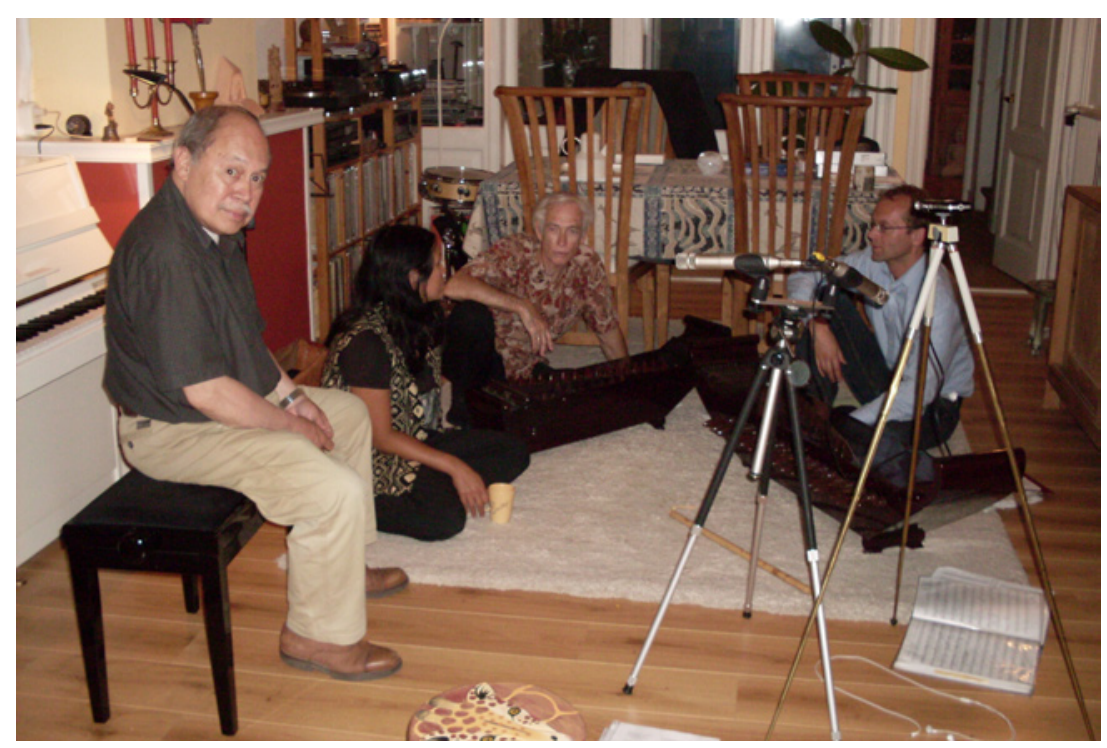

Image 9.4 Rehearsal of Dutch Cianjuran group Dangiang Parahiangan with piano at Ronald Bergman's home in The Hague, 22 July 2009. From left to right: Rob Agerbeek, Sinta Wullur, Wim van Zanten and Igor Boog (photo courtesy of Ronald Bergman).

\section{Conclusion}

The musical encounters between Jaap Kunst and Machjar Kusumadinata were characterized by a shared desire to develop a music theory for West Java. During my own research in the early 1980 os I was confronted with the obvious shortcomings in their theories, which were still being used in Bandung music schools. I therefore concentrated on the practical knowledge of musicians: music theory needs to be firmly based on the sound of music. In 2001-2004, Bandung conservatory staff members openly challenged Kusumadinata's theories and confirmed my findings of the 1980 . This has been an important step forward.

A new modal theory needs to be developed. The relevance of new modal theories should be checked with practitioners, possibly by methods using experimental research with perception tests. For this to succeed, music researchers in Bandung and elsewhere should receive better training in the methods and techniques of research and become exposed to international discussions in the field. If they want to have some international impact, they can no longer limit their discussions to the restricted area 
of West Java or Indonesia. At the same time, I hope that fine Sundanese musicians, like Uking Sukri in the past, will continue to inspire people with their musical performances and experiments.

At several universities in the United States there have been 'artists in residence' for many years. It is a system where musicians from foreign music cultures transfer their practical knowledge and at the same time work on their dissertations. Mantle Hood, one of Jaap Kunst's students, has played an active role in implementing this system to stimulate musical encounters. In a situation where Bandung staff members wish to improve their theoretical knowledge and Dutch scholars want to improve their practical knowledge of Sundanese music, this is a stimulating example to be followed.

\section{References}

Ati. Citra Musik 26 (26 September-2 October 1990): 12, 1990.

Barmara and Ida Achman. Perkembangan tembang/kawih Sunda. Bandung: Dua-R. 1958.

Berge, Tom van den. Van kennis tot kunst: Soendanese poëzie in de koloniale tijd. Ridderkerk: Ridderprint. [PhD dissertation University Leiden.] 1993.

—. Karel Frederik Holle: Theeplanter in Indië 1829-1896. Amsterdam: Bert Bakker, 1998.

Brandts Buijs, J.S. 'Uitslag van de prijsvraag inzake een Javaansch muziekschrift,' Djåwå 4: $1-17,1924$.

- 'Het gewone Javaansche tooncijferschrift (het Sålåsche-Kepatihanschrift)', Djåwå 2o: 87-106, 145-167, 1940.

Brinkgreve, Clara. Met Indië verbonden: Een verhaal van vier generaties 1948-1949. Zutphen: Walburg, 2009.

Cook, Simon. 'Parallel versions of tembang Sunda melodies', in: Wim van Zanten (ed.), Oideion: The performing arts world-wide, pp. 55-84. Leiden: Centre of Non-Western Studies, Leiden University. [CNWS Publications 35.] 1993.

Correspondence Kunst-Kusumadinata. 'Correspondence between Machjar Kusumadinata [Koesoemadinata] and Jaap Kunst'. Library of the University of Amsterdam, 1928-1954.

Ensiklopedi Sunda. Ensiklopedi Sunda: Alam, manusia, dan budaya, termasuk budaya Cirebon dan Betawi. Jakarta: Pustaka Jaya, 2000.

Hana Rs. 'Lalampahan Mang Uking Spk. di Inggris; Walikota Birmingham kagendam ku Cianjuran,' Mangle 1370 (1-7 October): 44-46, 1992.

Hardjito, Priadi Dwi. 'Kebinekaan laras, keserupaan laras, dan metode penetapannya', Panggung: Jurnal seni STSI Bandung 32: 40-53, 2004.

Heins, Ernst L. 'Goong renteng: Aspects of orchestral music in a Sundanese village'. PhD dissertation, University of Amsterdam, 1977.

- 'Jaap Kunst and the rise of ethnomusicology', in: Jaap Kunst, Indonesian music and dance. Traditional music and its interaction with the West, pp. 12-23. Amsterdam: Royal Tropical Institute/University of Amsterdam, 1994.

—. 'Brandts Buijs, Johann Sebastian (1879-1939)', in Biografisch Woordenboek van Nederland, www.inghist.nl/Onderzoek/Projecten/BWN/lemmata/bwn $5 /$ brandtsbuijs [13-032008] (last accessed 9 February 2011; original version included in Biografisch woordenboek van Nederland 5, Den Haag 2002), 2008.

Herdini, Heri. Metode pembelajaran kacapi indung dalam tembang Sunda Cianjuran. Bandung: STSI Press, 2003. 
'Peninjauan ulang terhadap teori laras dan surupan karya Machjar Angga Koesoemadinata', Panggung: Jurnal seni STSI Bandung 32: 54-66, 2004.

—. Raden Machjar Angga Koesoemadinata: Pemikiran \& aktivitasnya dalam dunia karawitan Sunda. Bandung: Sunan Ambu Press (STSI), 2007.

Hermawan, Deni. 'Tangga nada musik Sunda: Antara kenyataan teoretis dan praktis', Panggung: Jurnal seni STSI Bandung 21: 71-90, 2001.

Hernawan, Dedy. 'Tidak ada hubungan antara praktik laras dengan teori Machjar', Panggung: Jurnal seni STSI Bandung 22: 48-57, 2002.

Kartomi, Margaret J. Matjapat songs in Central and West Java. Canberra: National University Press, 1973.

Kedamaian. Bandung: Hidayat. [Cassette tape of kacapi-suling music (two zithers and bamboo flute) with (acoustic) piano. Performers: Bubi Chen (piano), Uking Sukri (kacapi indung), Dede Suparman (kacapi rincik), Endang Sukandar (suling). Cassette number 8902.] 1989.

Kunst, Jaap. De inheemse muziek en de zending. Amsterdam: Paris. [English edition of this lecture in Kunst 1994: 57-87], 1947.

- Around Von Hornbostel's theory of the cycle of blown fifths. Amsterdam: Indisch Instituut [Mededeling no. LXXVI, afd. Volkenkunde 27.], 1948.

- Musicologica. A study of the nature of ethno-musicology, its problems, methods and representative personalities. Amsterdam: Royal Tropical Institute. [Also reprinted in Kunst 1994: 88-147.], 1950.

—. Music in Java: Its history, its theory and its technique. Third enlarged edition, ed. Ernst L. Heins. The Hague: Nijhoff. Two vols. [First edition in Dutch: De toonkunst van Java, 1934.], 1973.

- Indonesian music and dance. Traditional music and its interaction with the West. A compilation of articles (1934-1952) originally published in Dutch, with biographical essays by Ernst Heins, Elisabeth den Otter and Felix van Lamsweerde. [Texts selected and edited by Maya Frijn and others]. Amsterdam: Royal Tropical Institute/University of Amsterdam, 1994.

Kunst, Jaap and R. Machjar Kusumadinata. 'Een en ander over pélog en sléndro', Tijdschrift voor Indische Taal-, Land-en Volkenkunde 69: 320-352 + tables, 1929.

Kusumadinata, Machjar Angga [also Koesoemadinata]. Ringkěsan pangawikan rinĕnggaswara (Ringkěsan elmuning kanajagan). Djakarta: Noordhoff-Kolff. [Second print ca. 1953; first impression ca. 1950.] n.d.

—. Ilmu seni-raras. Djakarta: Pradnja Paramita, 1969.

Moriyama, Mikihiro. Sundanese print culture and modernity in nineteenth-century West Java. Singapore: Singapore University Press, 2005.

Otter, Elisabeth den. 'Music in the Tropenmuseum: From Jaap Kunst to the present', in: Jaap Kunst, Indonesian music and dance. Traditional music and its interaction with the West, pp. 24-35. Amsterdam: Royal Tropical Institute/University of Amsterdam, 1994.

Powers, Harold S. 'Mode', in: Stanley Sadie (ed.), The new Grove dictionary of music and musicians, Volume 12: 376-450. London: Macmillan; New York: Grove Dictionaries of Music, 1980.

Rahn, Jay. 'Javanese Pélog tunings reconsidered', Yearbook of the International Folk Music Council 10: 69-82, 1979.

Roon, Marjolijn van. 'Jaap Kunst, government musicologist. An unusual incident in the colonial political history of the Netherlands East Indies', in: Wim van Zanten and Marjolijn van Roon (eds), Oideion: The performing arts world-wide, Volume 2, pp. 63-83. Leiden: Research School CNWS. [CNWS Publications 35.], 1995.

SEM. Society of Ethnomusicology, Jaap Kunst Prize, http: //webdb.iu.edu/sem/scripts/ prizes/prizesdetail.cfm?pID=3 (last accessed 30 January 2011), 2011.

Soepandi, Atik. Kamus istilah karawitan Sunda. Bandung: Satu Nusa. [First print 1988.], 1995.

Sukanda, Enip. Biografi Uking Sukri. Bandung: STSI Press, 1996. 
Sukri, Uking. 'Autobiographical notes', written in Indonesian on request of Wim van Zanten. [Unpublished manuscript.], 1988.

-. Pamelaran tembang Sunda 1. Bandung: Mitra Buana, 1989.

Tamura, Fumiko. 'The tone and scale system of Sunda', in: Fumio Koizumi, Yoshihiko Tokumaru and Osamu Yamaguchi (eds), Asian musics in an Asian perspective: Report of Asian traditional performing arts 1976, pp. 64-72. Tokyo: Heibonsha Limited, 1977.

Weintraub, Andrew N. "Theory in institutional pedagogy and "theory in practice" for Sundanese gamelan music', Ethnomusicology 37: 29-39, 1993.

Witzleben, J. Lawrence. 'Performing in the shadows: Learning and making music as ethnomusicological practice and theory,' Yearbook for Traditional Music 42: 135-166, 2010.

Zanten, Wim van. 'The tone material of the Kacapi in Tembang Sunda in West Java', Ethnomusicology 30: 84-112, 1986.

- Sundanese music in the Cianjuran style: Anthropological and musicological aspects of Tembang Sunda. Dordrecht, Holland/ Providence, USA: Foris. [With Demonstration cassette tape 9o'.], 1989.

_ . 'Notation of music: Theory and practice in West Java', in: Wim van Zanten and Marjolijn van Roon (eds), Oideion: The performing arts world-wide 2, pp. 209-233. Leiden: Research School CNWS. [CNWS Publications 35.], 1995.

- 'Between musicology and anthropology: Methodological issues in twentieth-century ethnomusicology in the Netherlands', in Han F. Vermeulen and Jean Kommers (eds), Tales from Academia: History of anthropology in the Netherlands, 1770-200o, Vol. 2: 937962. Nijmegen: NICCOS; Saarbrücken: Verlag für Entwicklungspolitik, 2002.

- 'Uking Sukri, seorang guru yang tahu batas kemampuannya, dunia pamirig dan perkembangan Tembang Sunda Cianjuran', key-note speech at the Seminar Panineungan Uking Sukri, STSI Bandung, 2 April 2005. See www.xs4all.nl/ wvzant27/Uking\%20 Sukri\%20seminar\%202005.pdf, 2005.

- The discourse on Islam and music in West Java, with emphasis on the music group ath-Thawaf', in: David D. Harnish and Anne K. Rasmussen (eds), Divine inspirations: Music and Islam in Indonesia, pp. 241-265. Oxford/ New York: Oxford University Press, 2011.

Zanten, Wim van and Uking Sukri. 'Performing Cianjuran music; Practical lessons for the course Anthropology of Music'. Unpublished materials, including a CD and transcribed music for all parts. Institute for Cultural Anthropology and Development Studies, University Leiden [earlier editions as from 1992.], 2004. 


\section{Appendix: Relative Cipher Notation by Kusumadinata}

In the table below, four Sundanese pentatonic tone systems are notated according to Kusumadinata's relative cipher notation system (Herdini 2003: 30, 2004: 65). The last two rows give the corresponding approximate Western notation and the absolute Sundanese cipher notation as used by Barmara and Achman (1958: 8-9). In this table ciphers represent the different tones. The distance between the ciphers in the table is (approximately) proportional to the musical interval between the tones, given in Western equal-tempered semi-tones (one column difference $\equiv$ one semitone $\equiv 100$ cent). Each row covers an octave of twelve semi-tones (or 1200 cent). The arrangement is from high notes on the left to low notes on the right. If we take the note in column 1 to be F, which is more or less standard in Cianjuran music, the first row of ciphers (pelog degung, pelog) represents the tones $\mathrm{F}, \mathrm{E}, \mathrm{C}, \mathrm{B} b, \mathrm{~A}, \mathrm{~F}$ and the second row (sorog madenda, $\operatorname{sorog}) \mathrm{F}, \mathrm{E}, \mathrm{D}, \mathrm{B}$, A, F. Note that the salendro intervals are not all multiples of semi-tones; the salendro note 2 is between $\mathrm{Eb}$ and $\mathrm{D}$, and note 5 between Ab and G; in the absolute Sundanese cipher notation these notes are notated as $2+$ and $5^{+}$.

The problem is that, according to Kusumadinata's relative system, on kacapi zithers tuned to pelog the cipher 1 would represent the tone F, produced by string 1; in sorog the cipher 1 would represent the tone

Table 1. Cipher notation by Kusumadinata

\begin{tabular}{|c|c|c|c|c|c|c|c|c|c|c|c|c|c|}
\hline \multirow{2}{*}{$\begin{array}{l}\text { Name tone } \\
\text { system } \\
\text { Pelog degung }\end{array}$} & \multicolumn{13}{|c|}{$\begin{array}{l}\text { Tones in Kusumadinata's cipher notation and approximate Western equivalents } \\
\text { when note in first column is F; the last row gives the Sundanese absolute cipher } \\
\text { notation (Barmara and Achman 1958: 8-9). }\end{array}$} \\
\hline & 1 & 2 & & & & 3 & & 4 & 5 & & & & 1 \\
\hline $\begin{array}{l}\text { Sorog } \\
\text { (madenda) }\end{array}$ & 3 & 4 & & 5 & & & & 1 & 2 & & & & 3 \\
\hline Mandalungan & 3 & & 4 & 5 & & & & 1 & 2 & & & & 3 \\
\hline Salendro & 1 & & 2 & & & 3 & & 4 & & 5 & & & 1 \\
\hline $\begin{array}{l}\text { Approximate } \\
\text { Western note } \\
(\text { when barang } \\
\equiv \mathrm{F})\end{array}$ & $\mathrm{F}$ & E & $\mathrm{Eb}$ & $\mathrm{D}$ & {$[\mathrm{Db}]$} & C & {$[\mathrm{B}]$} & $\mathrm{Bb}$ & A & $A b$ & {$[\mathrm{G}]$} & {$[\mathrm{Gb}]$} & $\mathrm{F}$ \\
\hline $\begin{array}{l}\text { Absolute } \\
\text { cipher notation } \\
\text { in West Java }\end{array}$ & 1 & 2 & $2+$ & $3^{-}$ & & 3 & & 4 & 5 & $5^{+}$ & & & 1 \\
\hline
\end{tabular}


$\mathrm{B} b$ produced by string 4 . To put it another way, the tone produced by the first string, as represented in the first column of Table 1 (三 Western note $\mathrm{F}$ in each of the four tone systems) would be notated with cipher 1 in pelog (degung) and salendro, but with cipher 3 in sorog (madenda) and mandalungan. 